\section{Thermoelasticity of Elastin}

THFRE is some controversy about the presence in elastin of an ordered structure ${ }^{1-3}$. Mammi et al. ${ }^{4}$ now report evidence for the occurrence of some degree of $\alpha$-helix conformation in the native protein. The conformation was previously ${ }^{5}$ observed in soluble elastin; the temperature eoefficient of the $\alpha$-holix had different values in solvents such as water or glycol. We have studied the thermoelastic behaviour of elastin in order to gain in. formation on its conformation ${ }^{6}$.

Earlier workers ${ }^{7,8}$ have found a large negative value for the energy component of the tensile force measured at constant length, prossure and under equilibrium swelling in water. They attributed this value to stress-induced crystallization.



Fig. 1. Variation of the teusile force $f$ with temperature $T$ for a collagen-free elastin sample in equilibrium swelling with water (the (ross-sectional area of the dry sample is $0.033 \mathrm{~cm}^{2}$ ). The elongation ratio (measured at $50^{\circ} \mathrm{C}$ ) is shown by 3 decreasing temperature; $\delta$ increasing temperature.

Hoeve and Flory ${ }^{9,10}$, however, attributed the internal energy changes to a reduction of the degree of swclling of elastin in water with increasing ternperature. They tried to get round the offect by performing a thermoelastic analysis in the presence of a water-glycol mixture whero the total volumo $V$ of the swollen (unstressed) network was independent of tomperature; that is, $(\partial V / \partial T)_{p e q}=0$ ( $e q$ denotes swelling equilibrium throughout the measurements). They concluded that elastin behaved as an ideal rubber: the fundamental elastic mechanism was purely entropic.

Hoeve and Flory were criticized ${ }^{11}$ for neglecting possible complications from water-glycol disproportionation during the measurement. This might, in fact, be significant in view of the solvent role of the temperaturecocfficient of the $\alpha$-helix conformation mentioned here ${ }^{5}$.

We have investigated the variation of length, width and thickness with temperature for a collagen-free clastin sample immersed in water. The volume of the sample (obtained from frozen ox ligamentum nuchae, cutting the sample in the direction parallel to the fibre axis of the ligamentum and removing the collagen component by autoclaving for $12 \mathrm{~h}$ at $120^{\circ} \mathrm{C}$ ) did not change over the range $50^{\circ}-74^{\circ} \mathrm{C}$. Measurements were fully reversible. The elastin-water system in this temperature range thus seems well suited for a thermoelastic analysis at constant volume. Such a method would avoid the difficulties experienced by early investigators 7,8 , who worked in a different temperature interval, and by Hoeve and Flory ${ }^{\theta}$, who used a two-component diluent.

The variation of the tensile force $f$ with temperature for elastin samples immersed in water and stretched at constant length $L$ is shown in Fig. 1 . Measurements were made as described elsewhere ${ }^{6,12}$, with excellent reproducibility and reversibility. The clongation ratio $\alpha$ reported was referred to the swollen unstretched length measured at $50^{\circ} \mathrm{C}$. The stress temperature coefficient actually measured, $(\partial f / \partial T)_{p} L_{e q}$. can be taken ${ }^{10,13}$ as cqual to the corresponding constant volume coefficient, $(\partial f)$ $\partial T)_{V L}$, because of the constaney of volume with temperature. The ratio of the energy component $f_{e}=(\partial E / \partial L)_{V T}$ to the total retractive force $f$ can therefore be written as

$$
\frac{f_{e}}{f}=1-\frac{T}{f}\left(\frac{\partial f}{\partial T}\right)_{p L e q}
$$

Table 1 shows our results.

Table 1. THERMOELASTIC DATA FOR AN ELASTIN SAMPLE IN EQULLBRIUM SWELLING WTTH WATER IN THE TEMPGRATURE RANGE $50^{\circ}-74^{\prime 2} \mathrm{C}$

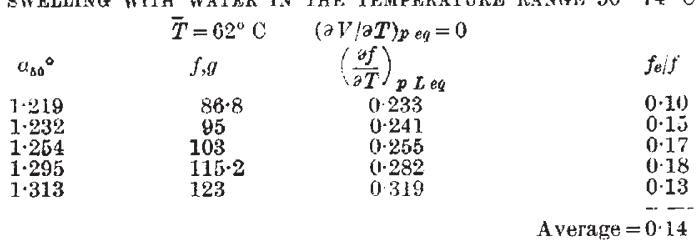

There is clearly a non-lauishing energy component, amounting to about 15 per cont of the total retractive force. Because the measurements pertain to constant volume conditions the results characterize the doformation of the molecular chains. Although we are confident that the fundamental elastic mechanism in elastin is not purely entropic, it is not easy to interpret the obscrved energy component in molecular terms. We suggest that non-isvenergetic minima might occur in the potentials of internal rotation of the polypeptide chain. Morenver, $f_{e}$ is positive, and so relatively compact conformations seern to be energetically favoured.

Institute of Histology,

D. VOLuin

University of Padua,

Padua, Ttaly.

Research Laboratory for

A. Cuferri

Polymor Technology and Rheologr,

National Research Council,

Areo) Felice (Naples),

Ttaly.

Received July 7, 1969.

1 Gotte, L., and Serafini-Frackssini, A.. .I. Atheroscler. Res., 3, 247 (1963),

2 Gotte, I., Mammi, M., and Peyin, C... in Symposium on Fibrous Proteins (edit. by (rewther, W. (i.), $2: 36$ (Butterworths, Australia, 1968)

${ }^{3}$ Cox, R. C., and Little, K., Proc. Roy. S's ., B, 155, 232 (1061).

- Mammi, M., Gotte, I., and Pezzin, G., Nature, 225, 380 (1070) (see pretedint article).

- Ilammi, M., Gotte, $\mathrm{J}_{\text {, }}$ and Pezzin, (i., Nuture, 220, 371 (1068); see also ammi, M., Gotte, d., and Pezzin. (i., Tutare, 220, 371 (1908); see also Chemistry and Molecild

${ }^{6}$ Ciferri, A., Trans. Furad. Soc., 5\%, 846 (1961).

7 Meyer, K. H., and Ferri, C., Pflïg. Arch. ges. Physiol., 238, 78 (1936).

${ }^{8}$ Wöhlisch, E., Weitnauer, H., Gruning. W., and Rohrbach, R., Kolloidzeitsehrift, 104, 14 (1943).

- Hoeve, C. A. J., and Flory, P. J., J. Amer. Chem. Soc., 80, 6523 (1058).

to Hocve, C. A. J., and Flory, P. J., J. H'olymer Sei., 60, 155 (1962).

11 Oplatka, A., Michaeli, J., and Katrhalsky. A., J. Polymer Sei., 46, 365 $(1960)$

${ }^{12}$ Puott, D., Ciferri, A., and Kajagh, I. V.. Binpolymers, 3, 461 (1065).

13 Bashaw, J., and smith, K. J., .J. I"tum, "*i., 6, 1041 (1968). 